\title{
Directed Expression of the Growth-Associated Protein B-50/GAP-43 to Olfactory Neurons in Transgenic Mice Results in Changes in Axon Morphology and Extraglomerular Fiber Growth
}

\author{
Anthony J. G. D. Holtmaat,, ${ }^{1,2}$ Paul A. Dijkhuizen, ${ }^{1}$ A. Beate Oestreicher, ${ }^{2}$ Herms J. Romijn, ${ }^{1}$ Nathalie M. T. \\ Van der Lugt, ${ }^{3}$ Anton Berns, ${ }^{3}$ Frank L. Margolis, ${ }^{4}$ Willem Hendrik Gispen, ${ }^{2}$ and Joost Verhaagen ${ }^{1,2}$ \\ ${ }^{1}$ Netherlands Institute for Brain Research, 1105 AZ Amsterdam-ZO, The Netherlands, ${ }^{2}$ Rudolf Magnus Institute for \\ Neuroscience, Department of Medical Pharmacology, 3584 CJ Utrecht, The Netherlands, ${ }^{3}$ The Netherlands Cancer \\ Institute, $1066 \mathrm{CX}$ Amsterdam, The Netherlands, and ${ }^{4}$ Roche Institute of Molecular Biology, Roche Research \\ Center, Department of Neurosciences, Nutley, New Jersey 07110
}

B-50/GAP-43, a neural growth-associated phosphoprotein, is thought to play a role in neuronal plasticity and nerve fiber formation since it is expressed at high levels in developing and regenerating neurons and in growth cones. Using a construct containing the coding sequence of B-50/ GAP-43 under the control of regulatory elements of the olfactory marker protein (OMP) gene, transgenic mice were generated to study the effect of directed expression of B-50/GAP-43 in a class of neurons that does not normally express B-50/GAP-43, namely, mature OMP-positive olfactory neurons. Olfactory neurons have a limited lifespan and are replaced throughout adulthood by new neurons that migrate into the upper compartment of the epithelium following their formation from stem cells in the basal portion of this neuroepithelium. Thus, the primary olfactory pathway is exquisitely suited to examine a role of B-50/GAP-43 in neuronal migration, lifespan, and nerve fiber growth. We find that B-50/GAP-43 expression in adult olfactory neurons results in numerous primary olfactory axons with enlarged endings preferentially located at the rim of individual glomeruli. Furthermore, ectopic olfactory nerve fibers in between the juxtaglomerular neurons or in close approximation to blood vessels were frequently observed. This suggests that expression of B-50/GAP-43 in mature olfactory neurons alters their response to signals in the bulb. Other parameters examined, that is, migration and lifespan of olfactory neurons are normal in B-50/GAP-43 transgenic mice. These observations provide direct in vivo evidence for a role of B-50/GAP-43 in nerve fiber formation and in the determination of the morphology of axons.

[Key words: growth-associated protein B-50/GAP-43, offactory marker protein, olfactory system, transgenic mice, axon morphology, process formation]

Received May 22, 1995; revised Aug. 1, 1995; accepted Aug. 4, 1995

We thank Gerben van der Meulen and Niko Bakker for preparation of the figures and Wilma Verweij and Tini Eikelboom for their secretarial assistance. Jacolien Coes, Jan Plaizier, Lotte Plantinga, and Paul Evers are acknowledged for their extensive and expert technical assistance. Special thanks go to Gerard Boer and Roman Giger for their critical reading of the manuscript. This work was supported by grants from NWO/GB-MW $(903.52 .121,030.94 .142)$ and a fellowship of the Royal Netherlands Academy of Arts and Sciences.

Correspondence should be addressed to J. Verhaagen, Netherlands Institute for Brain Research, Meibergdreef 33, 1105 AZ Amsterdam-ZO, The Netherlands.

Copyright (1) 1995 Society for Neuroscience 0270-6474/95/157953-13\$05.00/0
Adult nervous systems are comprised of a multitude of discrete nerve tracts. The formation and maintenance of these tracts is under the stringent control of intra- and extracellular molecules. The latter include growth factors, cell adhesion molecules, repulsive guidance cues and extracellular matrix components. A protein speculated to be crucial in the intracellular mechanisms that regulate nerve fiber formation is the growth-associated protein B-50/GAP-43.

B-50 has originally been discovered in an attempt to identify phosphoproteins involved in synaptic function (7wiers et al., 1978; reviewed in Benowitz and Routtenberg, 1987) and is equivalent to GAP-43, a protein specifically transported into growing axons (Benowitz et al., 1981; Skene and Willard, 1981a,b; reviewed in Skene, 1989). It is expressed at high levels in the developing nervous system (Biffo et al., 1990; Dani et al., 1991) and is induced after nerve injury (Benowitz et al., 1981; Skene and Willard 1981a,b; Verhaagen et al., 1988). A role of B-50/GAP-43 in nerve fiber outgrowth is controversial and has been the subject of intense study. Direct evidence supporting the notion that $\mathrm{B}-50 / \mathrm{GAP}-43$ is required for neurite formation was obtained by manipulating the levels of B-50/GAP43 in cultured cells. Treatment of primary neurons with antisense B-50/GAP-43 oligonucleotides interferes with neurite extension (Aigner and Caroni, 1993, 1995) and intracellular anti-B-50/ GAP-43 antibodies reduce neurite formation in neuroblastoma cells (Shea et al., 1991). Overexpression of B-50/GAP-43 in PC12 and neuro2A cells increases their sensitivity to outgrowthpromoting stimuli (Yankner et al., 1990; Morton and Buss, 1992), and expression of the protein in non-neuronal cells induces filopodia and structures with a morphology reminiscent of growth cones (Zuber et al., 1989; Widmer and Caroni, 1993; Verhaagen et al., 1994). On the other hand, a PC-12 cell line devoid of B-50/GAP-43 does extend fibers (Baetge and Hammang, 1991) and B-50/GAP-43 null-mutant mice have a largely normal nervous system, hut these mice do exhibit defects in pathfinding (Strittmatter et al., 1995).

To study the function of this growth-associated protein in vivo, we created transgenic mice that express B-50/GAP-43 in mature primary olfactory neurons. These neurons form the primary olfactory pathway, projecting from the olfactory neuroepithelium to the olfactory bulb, where they terminate in structures termed glomeruli (Fig. 1A). The olfactory neuroepithelium is distinct from other areas of the vertebrate nervous system since it retains 
A.

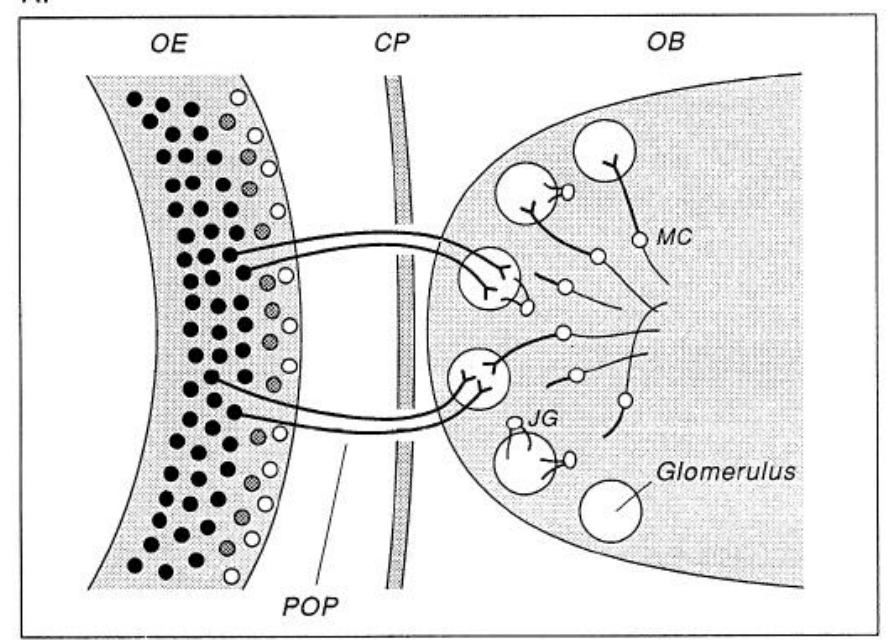

B.

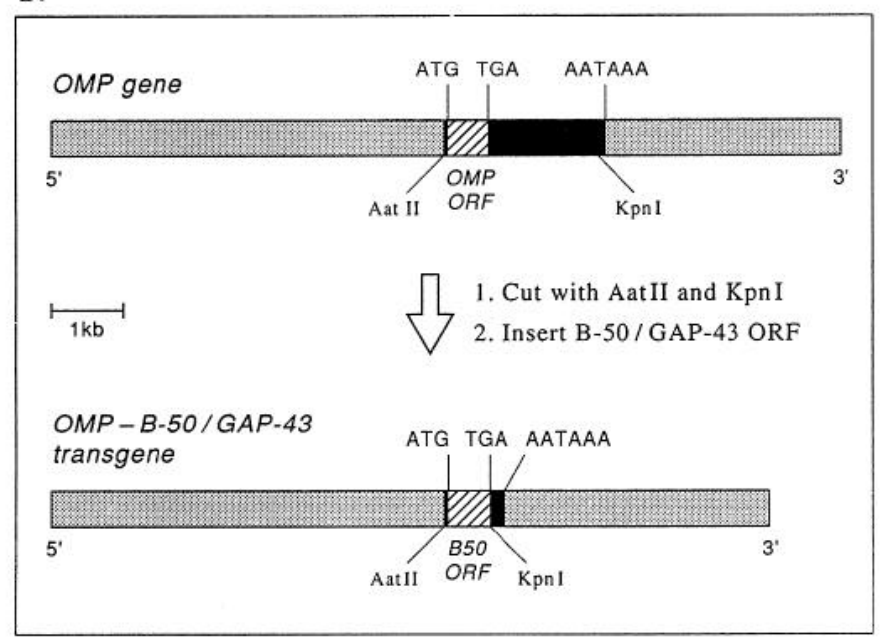

C.

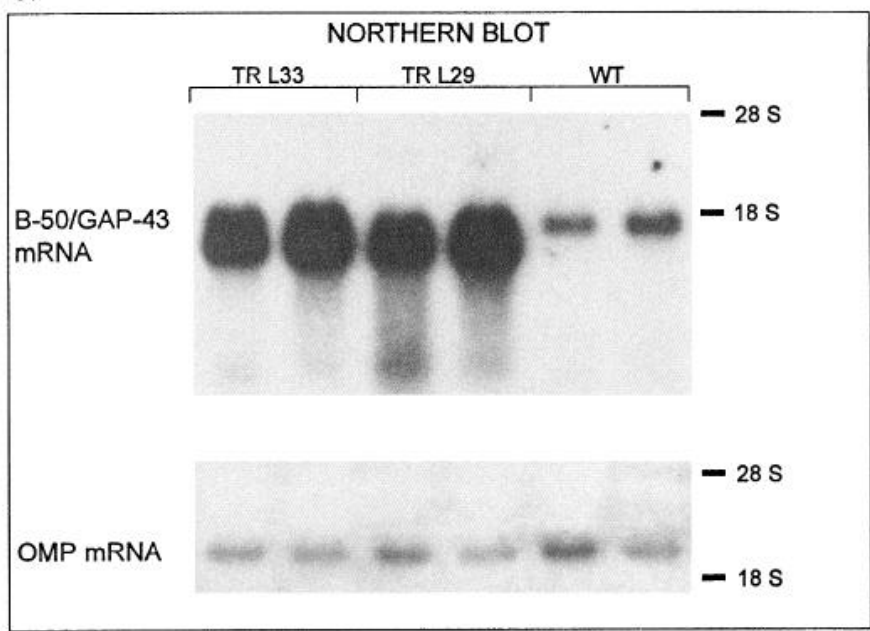

D.

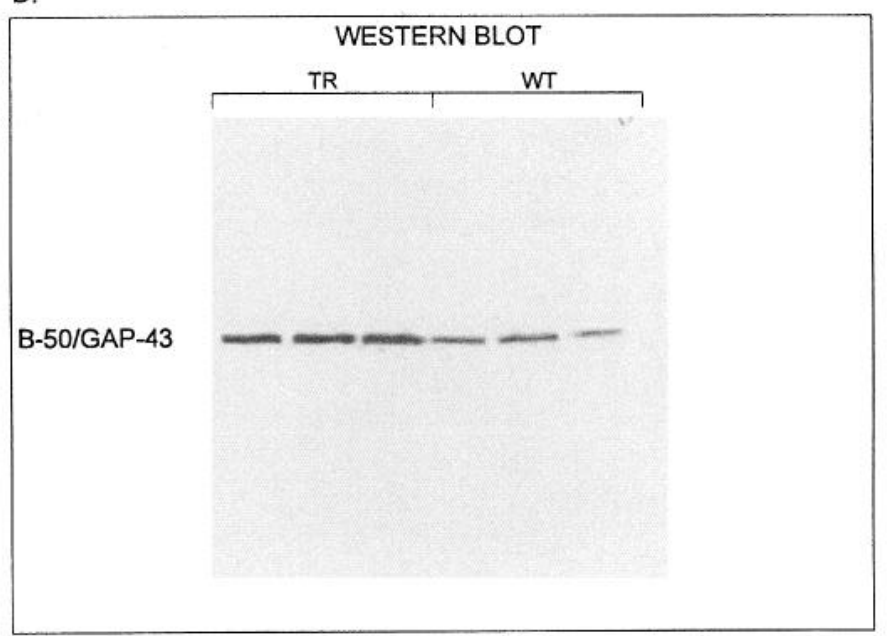

Figure 1. Directed expression of B-50/GAP-43 in the primary olfactory pathway of transgenic mice. $A$, Illustration of the anatomical relationships in the olfactory system. The olfactory neuroepithelium (OE) contains mature OMP-expressing neurons (black circles), immature olfactory neurons that express B-50/GAP-43 (gray circles) and stem cells (white circles). The axons of olfactory neurons form the primary olfactory pathway (POP) that penetrates through the cribriform plate (CP). Individual olfactory neurons project to olfactory bulb glomeruli where they form synapses on the dendrites of juxtaglomerular (JG) and mitral cells (MC). Glomeruli form a typical array of globular structures at the periphery of the olfactory bulb. Glomerular boundaries are determined by juxtaglomerular neurons and glial cells. $B$, Diagram of the construct used to generate transgenic mice that express B-50/GAP-43 under the control of the regulatory sequences of the OMP-gene. The OMP and B-50/GAP-43 ORFs and the restriction sites used for cloning are indicated. Details of the cloning procedure are given in Materials and Methods. $C$, Northern blot analysis of the olfactory epithelium of wild type (WT) and transgenic mice of line 33 (TR L33) and line 29 (TR L29). The blot was initially hybridized with a B-50/GAP-43 probe and exposed for $7 \mathrm{~d}$ (upper panel), subsequently stripped and reprobed with OMP followed by $3 \mathrm{~d}$ exposure time (lower panel). In wild type mice the native $1.6 \mathrm{~kb}$ B-50/GAP-43 mRNA is visible, while in the transgenic mice expression of transgenic mRNA of a slightly smaller size $(1.34 \mathrm{~kb})$ is detected. The positions of the $18 \mathrm{~S}$ and $28 \mathrm{~S}$ ribosomal RNA bands are indicated. Note that transgenic mice express high levels of the transgenic B-50/GAP-43 mRNA and that the OMP mRNA expression is similar in wild type and transgenic animals. $D$, Western blot detecting B-50/GAP-43 expression in wild type (WT) and transgenic animals (TR). Three adult 3 month old wild type mice and three transgenic littermates (TR) from L29 were sacrificed, olfactory bulb protein was extracted, separated by SDS-PAGE, blotted on nitrocellulose, and probed with anti-B-50/GAP-43 antibodies. Note that the transgenic olfactory bulb contains more B-50/GAP-43 and that the relative molecular weight of $\mathrm{B}-50 / \mathrm{GAP}-43$ in wild type and transgenic animals is identical.

precursor cells capable of replacing senescent or injured neurons that die (Moulton et al., 1970; Graziadei and Monti-Graziadei, 1978; Calof and Chikaraishi, 1989; Farbman, 1990; Mackay-Sim and Kittel, 1991; Schwartz Levey et al., 1991; Carr and Farbman, 1993). In adult wild type mice B-50/GAP-43 expression is restricted to a subset of neurons derived from these precursor cells (Verhaagen et al., 1989; Meiri et al., 1991; Schwob et al., 1992). Olfactory neuron maturation is accompanied by the upregulation of the expression of olfactory marker protein (OMP) and concomitant downregulation of B-50/GAP-43. In the trans- genic mice studied in this paper regulatory elements of the OMP-gene (Danciger et al., 1989) were combined with the coding sequence of B-50/GAP-43 in a transgene that conferred olfactory neuron-specific expression of B-50/GAP-43. This allows an analysis of the role of this growth-associated protein in several aspects of neuroplasticity, including neuronal migration, lifespan and morphology of primary olfactory axons.

We find that olfactory neurons expressing B-50/GAP-43 form axons often terminating in dilated grape-like structures, primarily located on the rim of the individual glomeruli. Olfactory 
axons were observed that penetrated into the juxtaglomerular layer or that did grow around blood vessels. These morphological phenomena were never observed in wild type littermates. Olfactory neuron migration and lifespan are normal in B-50/ GAP-43 transgenic mice. These observations demonstrate that expression of this growth-associated protein in adult olfactory neurons in vivo has a direct effect on the morphology and projection territory of primary olfactory axons.

\section{Materials and Methods}

Construction of the OMP-B-50/GAP-43 transgene and production of transgenic mice. To generate the OMP-B-50/GAP-43 hybrid transgene the entire OMP gene coding sequence was removed from an $11 \mathrm{~kb}$ OMP genomic clone (Danciger et al., 1989) and was replaced by the B-50/ GAP-43 open reading frame (ORF; Fig. $1 B$ ). To achieve this the OMP genomic clone was digested with AatII and KpnI. This resulted in removal of a $1.9 \mathrm{~kb}$ fragment containing $43 \mathrm{bp}$ of the OMP 5 '-untranslated sequence, the OMP ORF and $1.4 \mathrm{~kb}$ downstream of the TGA stopcodon but 210 bp $5^{\prime}$ of the OMP-polyadenylation signal. The two restriction sites used to remove the OMP coding sequence (AatII and KpnI) were introduced by PCR $5^{\prime}$ and $3^{\prime}$ to the B-50/GAP-43 ORF using a rat B-50/GAP-43 cDNA (Nielander et al.,1987) as template. The upstream primer consisted of a HindIII and an AatII restriction site, the $43 \mathrm{bp}$ OMP untranslated sequence and the first 16 nucleotides of the B-50/ GAP-43 ORF sequence. The downstream primer contained the last 16 nucleotides of the B-50/GAP-43 ORF and a $3^{\prime} \mathrm{KpnI}$ site. The PCR product generated with these primers was digested with HindIII and KpnI, cloned in pBluescript KS and sequenced. This revealed no PCR errors or cloning artefacts. The PCR product was removed from $\mathrm{p}$ Bluescript KS by digestion with AatII and KpnI and cloned in the AatII and $\mathrm{KpnI}$ digested OMP genomic clone. This resulted in a construct of $9.8 \mathrm{~kb}$ containing $5.5 \mathrm{~kb}$ of the OMP-gene upstream sequence (OMPpromoter), the B-50/GAP-43-coding sequence and $3.7 \mathrm{~kb}$ of the OMPgene $3^{\prime}$ sequence including the OMP-poly $\mathrm{A}^{+}$signal sequence (Fig. $i B)$. The transgene was removed from the plasmid by digestion with EcoRI, the resulting $9.8 \mathrm{~kb}$ fragment was gel purified dialyzed against sterile Millipore water and used for injection of mouse zygotes to generate transgenic mice essentially as described (Hogan et al., 1986). In short, the purified DNA was diluted to a concentration of $4 \mu \mathrm{g} / \mathrm{ml}$ and injected into the pronucleus of fertilized mouse eggs, recovered in cumulus from oviducts of superovulated $\Gamma V B / N$ females. After overnight culturing two-cell stage embryos were implanted into the oviducts of day 1 pseudopregnant FI foster females. Seventy-five mice were born from these mothers of which eleven had incorporated the transgene into tail-DNA. Nine of these mice passed the transgene to their offspring. These nine founders were used for breeding to generate transgenic lines.

Southern blot analysis. Transgenic mice were identified by Southern blotting of genomic tail DNA (Laird et al., 1991). Twenty $\mu \mathrm{g}$ DNA were digested with HindIII and separated by electrophoresis on a $0.75 \%$ agarose gel. The DNA was denatured with $0.5 \mathrm{M} \mathrm{NaOH} / 1.5 \mathrm{M} \mathrm{NaCl}$ and neutralized with $0.5 \mathrm{M}$ Tris $-\mathrm{HCl} \mathrm{pH} 6.0 / 1.5 \mathrm{M} \mathrm{NaCl}$ for $45 \mathrm{~min}$. The DNA was blotted on a nylon membrane (GeneScreen Hybridization Transfer Membrane NEF984; NEN Research Products, Boston, MA) denaturated with $0.5 \mathrm{M} \mathrm{NaOH}$ for $1 \mathrm{~min}$ and neutralized for 1 min with $0.5 \mathrm{M}$ Tris-IICl pII $6.0 / 1.5 \mathrm{M} \mathrm{NaCl}$, cross-linked to the membrane by a $2 \mathrm{~min}$ exposure to $\mathrm{UV}$-light $(245 \mathrm{~nm})$ and prehybridized at $68^{\circ} \mathrm{C}$ in 0.5 $\mathrm{M} \mathrm{Na}_{2} \mathrm{HPO}_{4} \mathrm{pH} \mathrm{7.2,7 \%} \mathrm{SDS}$, and $250 \mu \mathrm{g} / \mathrm{ml}$ sonicated salmon sperm DNA. Finally, the membrane was hybridized at $68^{\circ} \mathrm{C}$ for $14 \mathrm{hr}$ with a random prime ${ }^{32} \mathrm{P}-$-labeled $\mathrm{B}-50 / \mathrm{GAP}-43 \mathrm{cDNA}$ in the same solution.

Northern blot analysis. Total RNA from olfactory neuroepithelium was prepared by tissue homogenization in RNAzol (Cinna/Biotecx, Friendswood, USA), extraction with chloroform and precipitation from the aqueous phase with isopropanol according to the manufacturer's instructions; $15-20 \mu \mathrm{g}$ of RNA was separated on a $1.5 \%$ agarose gel in $10 \mathrm{~mm}$ sodium phosphate and subsequently transferred to a nylon membrane (GeneScreen Hybridization Transfer Membrane NEF984; NEN Research Products, Boston, MA) in $20 \times$ SSC. The membrane was exposed to UV light ( $2 \mathrm{~min}$ ) and baked at $80^{\circ} \mathrm{C}$ for $2 \mathrm{hr}$. Prehybridization and hybridization was performed as described for Southern blot analysis. Initally the blot was hybridized with a B-50/GAP-43 cDNA probe, exposed for $7 \mathrm{~d}$ using Kodak X-OMAT film, subsequently stripped, reprobed with an OMP CDNA probe, and exposed for $3 \mathrm{~d}$.

Western blot analysis. For Western blot analysis, olfactory bulbs were dissected from wild type and transgenic mice and homogenized in TBS $(10 \mathrm{~mm}$ Tris- $\mathrm{HCl} \mathrm{pH} 7.5,0.9 \% \mathrm{NaCl})$ at $4^{\circ} \mathrm{C}$. Equal concentrations of protein, determined according to Lowry et al. (1951) in denaturing sample buffer were used for electrophoresis in $11 \%$ polyacrylamide-sodium dodecyl sulfate gels (Zwiers et al., 1976). Separated proteins were transferred to nitrocellulose membranes (Towbin et al., 1984). The membrane was preincubated in TBS/gelatin/TX-100 (TBS containing $0.25 \%$ gelatin and $0.5 \%$ Triton $\mathrm{X}-100$ ) and immunostained with polyclonal antibodies (derived from antiserum \#8921; Oestreicher et al., 1983) against B-50/GAP-43 (dilution 1:1000) under standard conditions (Verhaagen et al., 1988).

Immunocytochemistry. Mice were deeply anesthesized and perfused with $50 \mathrm{ml}$ phosphate-buflered saline (PBS) pH 7.4 followed by 100 $\mathrm{ml}$ of $2 \%$ paraformaldehyde (PFA) in $0.1 \mathrm{M}$ phosphate buffer $\mathrm{pH}$ 7.4. Olfactory turbinates and bulbs were dissected and postfixed in 2\% PFA for $12 \mathrm{hr}$ at $4^{\circ} \mathrm{C}$. The turbinates were decalcitied in $250 \mathrm{~mm}$ ED'l'A, 50 mM phosphate buffer, $\mathrm{pH} 7.4$. For cryosections, olfactory tissues were cryoprotected by immersion in $7.5 \%$ and $15 \%$ sucrose solutions at $4{ }^{\circ} \mathrm{C}$. Tissues were immersed in Tissue-tek (O.C.T Compound 4583; Miles Inc., Elkhart, IN) and frozen in dry ice-cooled isopentane. Ten micrometer thick cryostat sections were mounted on poly-L-lysine-coated microscope slides, washed with TBS/TX-100 (TBS containing $0.5 \%$ Triton X-100) and preincubated with TBS/gelatin/TX-100 for $30 \mathrm{~min}$. B-50/ GAP-43 was detected with affinity-purified polyclonal rabbit antibodies derived from antiserum \#8921 (dilution 1:1000; Oestreicher et al., 1983) and OMP was detected by polyclonal goat antibodies (antiserum \#255; dilution 1:5000; Keller and Margolis, 1975). Sections were incubated overnight at $4^{\circ} \mathrm{C}$ and subsequently washed with TBS/TX-100. In single staining procedures, sections were incubated for $\mathrm{l} \mathrm{hr}$ at room temperature with biotinylated anti-rabbit and anti-goat IgGs (diluted 1:100 in TBS/TX-100) and subsequently visualized with the avidin/biotin/peroxidase method (Vectastain ABC Kit; Vector Laboratories, Burlingame CA), using diaminobenzidine (DAB; $0.5 \mathrm{mg} / \mathrm{ml} 10 \mathrm{~mm}$ Tris $\mathrm{pH} \mathrm{7.6)}$ as the chromogen, according to the descriptions supplied within the kit. For confocal laser scanning analysis of olfactory bulbs, $30 \mu \mathrm{m}$ vibratome sections were prepared and incubated with primary antibodies according to the procedure described above. For double labeling binding of primary antibodies was visualized with dichlorotriazinylamino fluorescein (DTAF) conjugated anti-rabbit- and Texas red conjugated antigoat IgGs (Jackson Immuno Research Laboratories, West Grove). Sections were mounted in Vectashield mounting medium (Vector laboratories) and examined on a Zeiss confocal laser scanning microscope 410 , equiped with two different lasers emitting at 488 and $543 \mathrm{~nm}$, and the appropriate filters to prevent cross-talk. A stack of eight focal planes ( $1 \mu \mathrm{m}$ intervals) was imaged for both fluorophores, using oil immersion objectives (40x: plan-neofluor, $\mathrm{NA}=1.3 ; 63 \times$ : plan-apochromat, NA $=1.4$ ), whereafter one single projection was made by overlaying these focal planes in the z-direction.

Detection of BrdU labeled cells. Mice were injected intravenously with $20 \mu \mathrm{g} / \mathrm{gm}$ body weight of bromodeoxyuridine (BrdU; Boehringer, Mannheim, Germany) dissolved in sterile saline. At the appropriate days after the BrdU injection, the mice were perfused, dissected and tissue was frozen as described in the previous section. Ten micrometer cryostat sections were rinsed with PBS, postfixed in $70 \%$ ethanol for 2 min and denaturated with $50 \%$ formamide, $4 \times \mathrm{SSC}$ at $62^{\circ} \mathrm{C}$ for $5 \mathrm{hr}$. Subsequently sections were treated for $1 \mathrm{hr}$ with $2 \mathrm{~N} \mathrm{HCl}$ at $37^{\circ} \mathrm{C}$, neutralized with $0.1 \mathrm{M}$ Tris-HCl (pH 7.5), preincubated with TBS/gelatin/TX-100, and incubated with monoclonal anti-BrdU antibodies (Boehringer), diluted 1:16 in TBS/gelatin/TX-100. The subsequent steps were performed as described in the previous section.

Quantification of B-50/GAP-43- and BrdU-positive cells. The number and position of B-50/GAP-43 or BrdU-positive neurons in the olfactory epithelium was determined with a computerized image analysis system (DIFA, Breda, The Netherlands). Two 2-3 mm stretches of septal epithelium per animal, approximately $100 \mu \mathrm{m}$ apart were analyzed on a television screen with a $20 \times$ objective using an Olympus BH-2 microscope equipped with a video camera linked to an IBM computer. Two parameters were determined: (1) the number of stained cells per $1 \mathrm{~mm}$ epithelium, and (2) the distance of the labeled nuclei from the basal lamina was measured as percentage of the total height between the basal lamina and the surface of the epithelium. A BrdU-stained neuron was considered positive when the nucleus contained at least three labeled dots of chromatin

Golgi preparalions. Mice were anesthesized and perfused with 100 $\mathrm{ml} 1 \%$ PFA and $1.25 \%$ glutaraldehyde followed by $25 \mathrm{ml} 4 \%$ PFA and 
$5 \%$ glutaraldehyde in $0.08 \mathrm{M}$ cacodylate buffer $(\mathrm{pH} 7.3)$. The hrains were dissected and left in fixative for $48 \mathrm{hr}$. The bulbs were dissected and processed for light microscopy using an adaption of the Golgitechnique for electron microscopy (Cameron et al., 1991). In short, bulbs were immersed for $5 \mathrm{~d}$ in $2 \%$ potassium dichromate and $5 \%$ glutaraldehyde, transferred to $3.5 \%$ potassium dichromate and impregnated with $0.75 \%$ silver nitrate. Vibratome sections $(100 \mu \mathrm{m})$ were cut under $70 \%$ ethanol, dehydrated, embedded, and studied by light microscopy.

\section{Results}

The olfactory marker protein promoter directs high level B-50/ $G A P-43$ expression to mature olfactory neurons in transgenic mice

In three out of a total of nine transgenic lines (L28, L29, and L33) obtaincd with the OMP-B-50/GAP-43 construct (Fig. 1B), immunohistochemical staining of sections of olfactory neuroepithelium and olfactory bulb of young adult offspring (5-7 weeks of age) revealed expression of B-50/GAP-43 in numerous olfactory neurons in the upper three fourths of the epithelium as well as in their projections in the glomeruli. Norhtern blot analysis of RNA extracted from olfactory neuroepithelium reveals an increased level of B-50/GAP-43 mRNA while the levels of OMP mRNA expression are not changed (Fig. 1C). Western blot analysis of olfactory bulb extracts from offspring of L29 demonstrated that the transgenic olfactory bulb contains more B-50/ GAP-43. Furthermore, B-50/GAP-43 in samples of transgenic and wild type mice migrates to the same position in the gel (Fig. 1D). Five of the nine lines (L30, L31, L32, L37 and L38) expressed B-50/GAP-43 in a small subset of olfactory neurons and consequently in sparse olfactory axons distributed throughout the olfactory bulb glomeruli. One line (L35) did not express the transgene. The unequal pattern of expression of a protein in different transgenic lines generated with the same construct has been noted before and is probably due to different genomic insertion sites of the transgene (Palmiter and Brinster, 1986; Jaenisch, 1988). Southern blot analysis of tail DNA showed that the differential expression patterns of B-50/GAP-43 in transgenic olfactory epithelium did not correlate with the number of copies of the transgene. For instance, high expressing heterozygous mice from L29 and L33 had 31 copies and 14 copies of the transgene respectively, while the low expressing line L30 had 32 copies and L35, the nonexpressing line, contained 7 copies of the transgene (data not shown). Based on the observed expression patterns of B-50/GAP-43 five transgenic lines (L29 and L33: lines with abundant expression in numerous mature olfactory neurons; L30 and L32: lines with a relatively low number of B-50/GAP-43 expressing olfactory neurons; L35: a line with no expression of the transgene) were chosen for further study of phenotypic effects of B-50/GAP-43 expression on mature olfactory neurons.

In both wild type and transgenic mice of L29 and L33 the number of OMP-positive neurons increased progressively with age, and the OMP-containing cell layer increased in thickness from about two cells at P5 to three to five cells at P17 (Fig. 2C) and six to eight OMP-positive cells in adult animals. In wild type animals the levels of B-50/GAP-43 in the OMP-expressing neurons decreased gradually as previously reported (Fig. $2 A, D$; Verhaagen et al., 1989). In transgenic animals a complement of heavily stained B-50/GAP-43 positive cells persisted in the upper compartment of the epithelium. This could clearly be seen on PI7 and is most obvious in young adult and adult animals (Fig. $2 B, E$ ). The appearance of these $\mathrm{B}-50 / \mathrm{GAP}-43$ positive cells is consistent with the action of the OMP promoter and demonstrates that the transgene is transcriptionally active in a way very similar to the native OMP-gene.

Visual inspection of sections of the olfactory neuroepithelium and olfactory bulbs of the first young adult (5-7 weeks of age) and adult ( 3.5 months of age) transgenic offspring of the highexpressing lines revealed two phenotypic consequences of directed B-50/GAP-43 expression in the primary olfactory pathway: (1) in the basal region of the olfactory neuroepithelium a clear decrease in the number of $\mathrm{B}-50 / \mathrm{GAP}-43$ positive immature cells, that are normally observed in the basal region of this epithelium, occurred (Fig. $2 D, E$ ); (2) in the glomerular layer of the olfactory bulb of transgenic animals numerous dense B-50/ GAP-43 positive structures were observed presumably associated with primary olfactory axons (Fig. $3 C, E$ ). In several instances B-50/GAP-43 positive fibers appeared to extend for a short distance over the glomerular boundary, resulting in irregular-shaped glomeruli (Fig. 3F).

\section{Olfactory neuron turnover is normal in B-50/GAP-43 transgenic neuroepithelium}

Quantitative comparison of sections of L29 and L33 wild type and transgenic litter mates revealed a decrease in the number of B-50/GAP-43 positive neurons in the basal region of the epithelium from $88 \pm 4$ cells $/ \mathrm{mm}$ septal epithelium in wild type mice to $21 \pm 3$ cells $/ \mathrm{mm}$ in transgenic mice (Fig. $5 \mathrm{~A}$ ). This effect was clearly related to the transgenic expression of $\mathrm{B}-50 / \mathrm{GAP}$ 43 in the upper compartment of the epithelium since offspring from a transgenic line that did not express the transgene (L35) had a normal phenotype (Fig. 5A). These observations could indicale that transgenic expression of B-50/GAP-43 in the upper compartment of the epithelium results in changes in migration and/or turnover of olfactory neurons. In order to examine these possibilities BrdU-labeling studies were performed in postnatal and in adult mice.

BrdU-labeling study in postnatal mice. To assess the fate of olfactory neurons born during postnatal development of the olfactory epithelium, $12 \mathrm{~d}$ old mice pups (four litters of wild type $\times$ L29 transgenic mouse couples) were injected with BrdU. Mice were sacrificed at $17 \mathrm{~d}(n=5$ wild type mice and $n=5$ transgenic mice) and at 47 days of age ( $n=10$ wild type mice and $n=12$ transgenic mice). The number, pattern and age related changes of BrdU-positive cells found in transgenic mice were not different from wild type mice (Fig. 4). In $47 \mathrm{~d}$ old mice the number of BrdU-positive cells dropped by about $70 \%$ in the epithelium in both transgenic and wild type mice (Fig. 4A). In $17 \mathrm{~d}$ old mice the BrdU-positive cells were located in the basal one-third of the epithelium and in $47 \mathrm{~d}$ old mice they were present in a scattered pattern throughout the epithelium (Fig. $4 B$ ).

BrdU-labeling study in adult mice. Three to 4 month old mice (L.29: wild type $n=26$, transgenic $n=38$; L33: wild type $n=$ 18 , transgenic $n=20$ ) were sacrificed at $1,3,8$, and $30 \mathrm{~d}$ after injection of BrdU, the number of BrdU positive cells in the septal olfactory neuroepithelium was counted at each timepoint and at 8 and $30 \mathrm{~d}$ postinjection the relative position of $\mathrm{BrdU}$ positive cells in the epithelium was determined. At all time points BrdU cell counts were similar in wild type and transgenic animals (Fig. $5 B$ ) and at 8 and 30 d the distribution of the cells was similar in wild type and transgenics (Fig. 5C,D). Cells examined at 1 and $3 \mathrm{~d}$ after BrdU injection were located adjacent to the basal lamina (data not shown). At $8 \mathrm{~d}$, BrdU-positive cells 

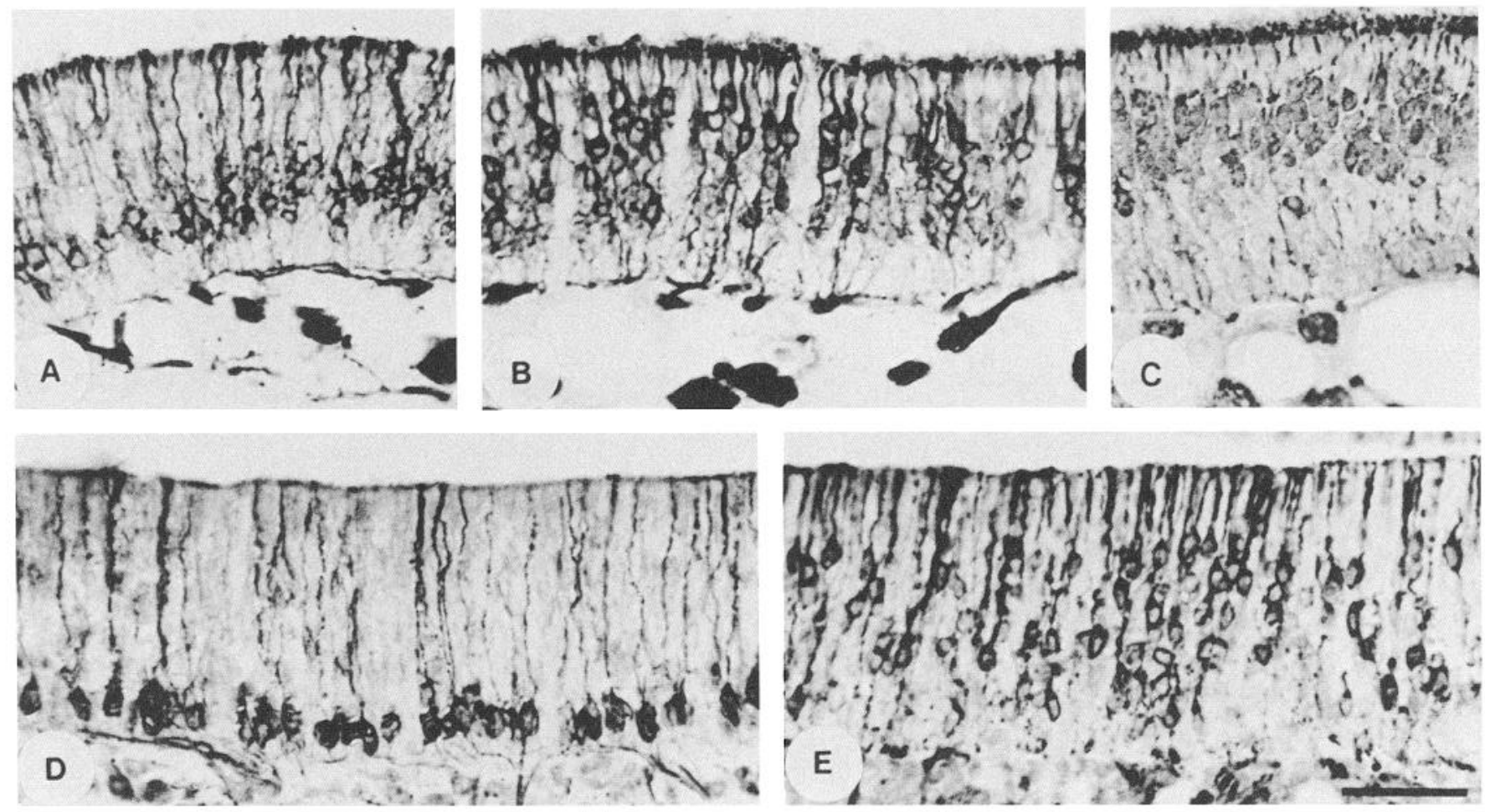

Figure 2. Expression of B-50/GAP-43 and OMP in olfactory neuroepithelium of P17 and 3.5 months old wild type and transgenic mice and decrease in the number of B-50/GAP-43 positive cells in the basal region of the epithelium. All photomicrographs are taken from transgenic and wild type littermates derived from L29. Expression of B-50/GAP-43 $(A, B, D, E)$ and OMP $(C)$ in olfactory epithelium of P17 $(A-C)$ and 3.5 month old $(D, E)$ wild type $(A, D)$ and transgenic mice $(B, C, E)$. In P17 wild type mice B-50/GAP-43 expression is still high in the lower half of the epithelium and has decreased in the upper portion of the epithelium $(A)$ containing the OMP-positive olfactory neurons $(C)$. In P17 transgenic animals an additional cohort of B-50/GAP-43 positive cells $(B)$ in the upper half of the epithelium corresponding in position to the population of OMP-positive cells $(C)$ can be clearly seen. In wild type adult 3.5 months old mice $(D)$ B-50/GAP-43 expression is restricted to a relatively small population of immature olfactory neurons in the basal portion of the epithelium. In contrast, in transgenic mice B-50/GAP-43 positive olfactory neurons populate the upper three-fourths of the epithelium $(E)$. These observations indicate that the transcriptional activation of the OMP-B-50/ GAP-43 transgene is consistent with the action of the native OMP gene. This figure also documents the decrement in B-50/GAP-43 positive neurons in the transgenic epithelium (compare $D$ and $E$ ). Scale bar, $50 \mu \mathrm{m}$.

had migrated into and through the affected region of the epithelium, that is, the region that exhibited a decrement in B-50/GAP43 positive cells in transgenic animals (Fig. $5 C$ ). After $30 \mathrm{~d}$ the BrdU labeled neurons were distributed throughout the neuroepithelium and the number of BrdU-positive cells had dropped to about $10 \%$ of the original cohort of BrdU-positive cells (Fig. $5 B)$. Overall, the results of the BrdU-experiments suggest that the turnover of olfactory neurons in the B-50/GAP-43 transgenic neuroepithelium is normal in terms of neurogenesis, migration, and turnover.

\section{Transgenic expression of B-50/GAP-43 in mature olfactory neurons results in morphological changes in their projections in the olfactory bulb}

Light microscopical analysis of the olfactory bulb began with a general assessment of the distribution of B-50/GAP-43 and OMP with conventional immunohistochemical staining of vibratome sections using $\mathrm{DAB}$ to visualize the distribution of both antigens in separate sections. In adult wild type mice the previously documented complementary distribution of B-50/GAP43 and OMP was observed (Fig. $3 A, B$; Verhaagen et al., 1989). In contrast, in the glomeruli of olfactory bulbs of transgenic offspring of the high-expressing lines L29 and L33 glomeruli were immunoreactive for both B-50/GAP-43 and OMP (Fig. $3 C, D)$. In low expressing lines individual B-50/GAP-43 positive axon profiles entered the glomeruli and formed intraglomerular terminal axon arbors (Fig. $3 E$ ). In low and in high expressing lines we noted densely stained B-50/GAP-43 immunoreactive dots (Fig. 3C,E). These immunoreactive "hot spots," often as large as $8 \mu \mathrm{m}$, occurred throughout the glomerulus, but were primarily located on the rim of the glomerulus (Fig. $3 C$ ). Due to the relatively low density of $\mathrm{B}-50 / \mathrm{GAP}-43$ positive fibers in L30 and L32 transgenic mice, it was possible to conclude that individual nerve fibers were often topped with a densily stained "hot spot" (Fig. 3E), suggesting that these structures represent enlarged nerve endings. Furthermore, we observed B-50/GAP43 immunoreactivity associated with intra- and extraglomerular blood vessels (Fig. $3 C$ ). Although antigen localization with DAB as chromogen has a relatively low resolution, interesting alterations were noted in the distribution of OMP in transgenic animals as compared to the classical and well documented distribution of OMP in wild type mice (compare Fig. $3 B$ and $3 D, G$ ). First of all, in glomeruli of transgenic animals concentrations of OMP immunoreactive dots were present, in size and location resembling to the B-50/GAP-43 "hot spots" (Fig. 3D). Secondly, blood vessels in glomeruli, or just adjacent to glomeruli, were often surrounded by OMP-positive nerve fibers in transgenic mice (Fig. 3D). Thirdly, occasional OMP-positive olfactory axons penetrated in between juxtaglomerular cells creating irregular shaped glomeruli (Fig $3 G$ ). These aberrant patterns of OMP 

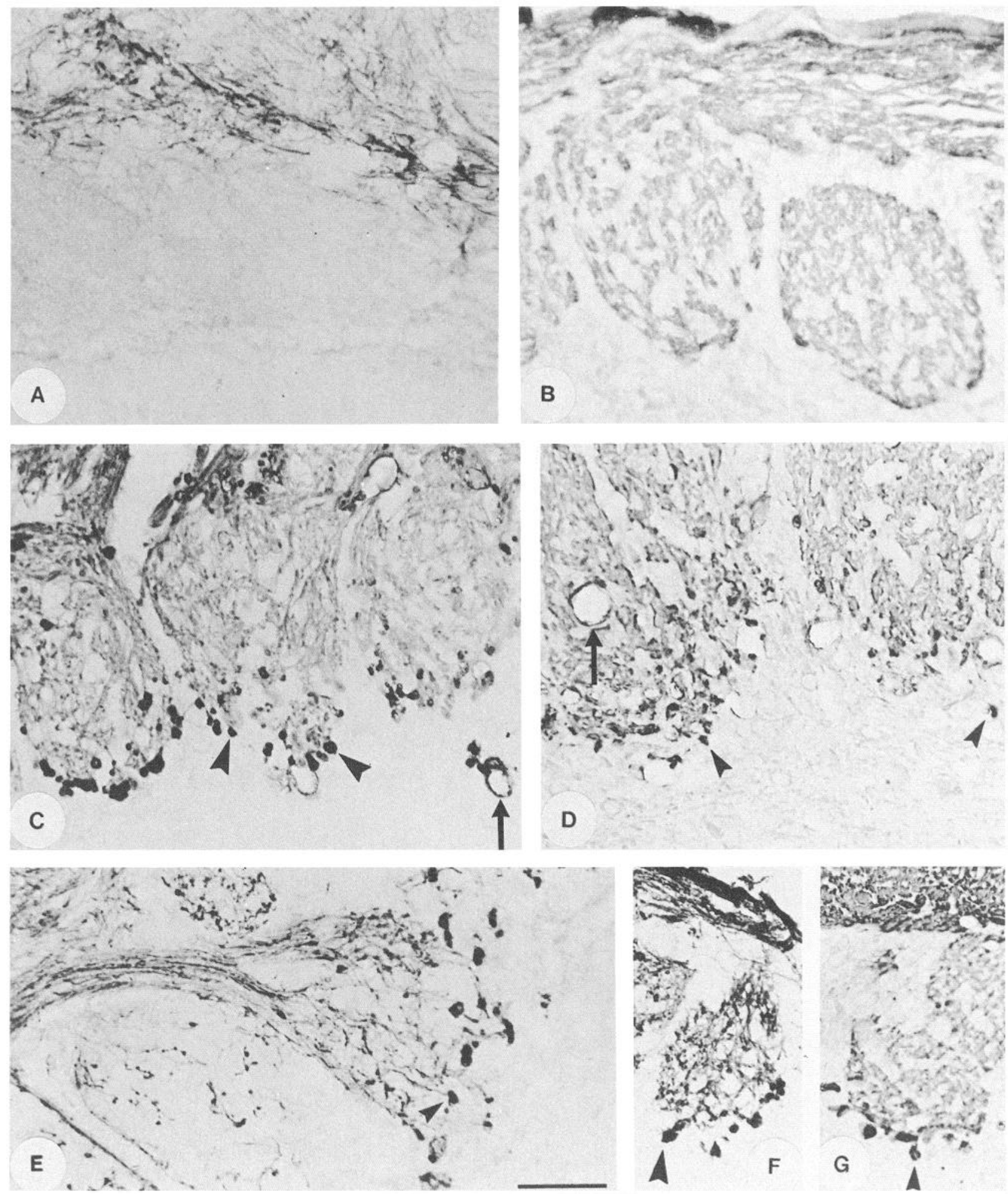

Figure 3. Immunohistochemical staining of B-50/GAP-43 and OMP in the olfactory bulb of transgenics reveals immunoreactive "hot spots" predominantly located at the edge of glomeruli and blood vessels contacted by primary olfactory fibers. Photomicrographs were taken from transgenic mice and wild type littermates of $\mathrm{L} 29(A-D)$ and $\mathrm{L} 33(F, G)$. E is derived from the low expressing line L30. $A$ and $B$, Olfactory bulb sections of wild type animals stained for B-50/GAP-43 $(A)$ and OMP $(B)$. Staining for OMP visualizes the glomeruli as more or less circular structures with well-defined sharp edges. $C-G$, Olfactory bulb sections of transgenic mice stained for B-50/GAP-43 $(C, E, F)$ and OMP $(D, G)$. Note the B-50/ GAP-43 and OMP immunoreactive "hot spots" predominantly localized at the rim of individual olfactory glomeruli (arrowheads) and immunoreactivity associated with blood vessels (arrows). By virtue of the limited number of B-50/GAP-43 positive fibers in the low-expressing line L-30 several of the dense immunoreactive spots can be seen to be connected to olfactory nerve fibers (arrowhead in $E$ ) suggesting that these structures represent enlarged nerve endings. $F$ (B-50/GAP-43) and $G(\mathrm{OMP})$ show occasional immunoreactive projections that start at the glomerular edge thus creating irregular shaped glomeruli. Scale bar, $50 \mu \mathrm{m}$. 

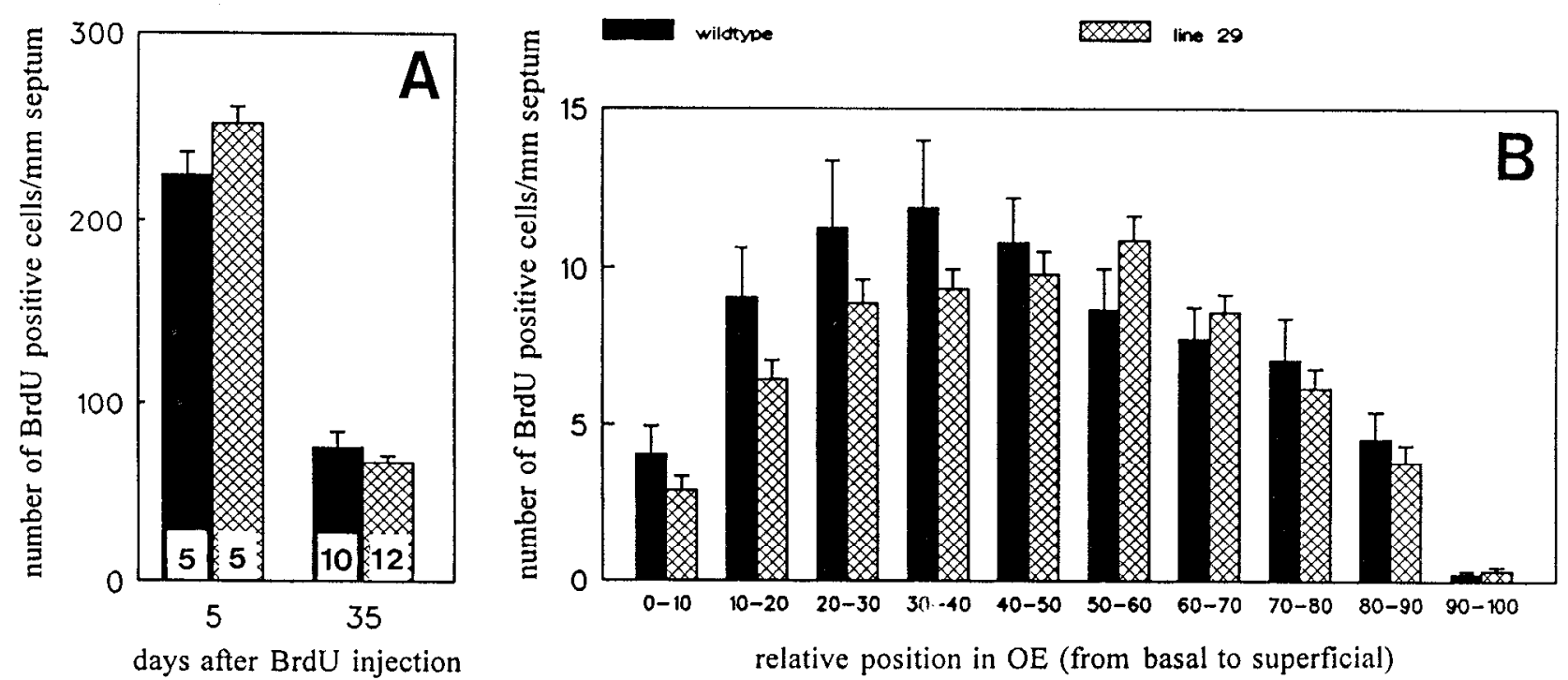

Figure 4. Basal cell division, migration and survival of cells in the olfactory epithelium of postnatal and young adult wild type and transgenic mice is normal. P12 mouse pups (L29) were injected with BrdU. A, Mice were sacrificed at 17 and $47 \mathrm{~d}$ of age and the number of BrdU positive cells was counted in the septal epithelium. $B$, In $47 \mathrm{~d}$ old animals the distribution of the cells in the olfactory epithelium is depicted as the number of BrdU positive cells along a $1 \mathrm{~mm}$ stretch of septal epithelium (basal is $0 \%$; most superficial is $100 \%$ ). The data are expressed as the mean \pm SEM and the number of animals in each group is indicated in the bars. An two-way ANOVA revealed no statistically significant difference between the position of BrdU-positive cells in the epithelium of transgenic and wild type mice $(F=1.167, p=3.18)$.

distribution were not seen in wild type litter mates and suggest that B-50/GAP-43 might have an effect on primary olfactory axon growth and morphology.

Confocal laser scanning microscopy on double-immunostained sections was performed to examine the relationship between the transgenic expression of B-50/GAP-43 in primary olfactory axon arbors and the observed aberrant patterns of OMPpositive primary olfactory projections in the bulb. Intraglomerular B-50/GAP-43 "hot spots" virtually always colocalized with concentrations of OMP immunoreactivity (Fig. $6 C, D$ ). The resolution of the confocal microscope was sufficient to ascertain that highly immunoreactive B-50/GAP-43 axon arbors terminated in abnormally enlarged OMP-positive boutons (Fig. 7A-D). In the low expressing lines individual olfactory axons exhibited varicosities and extremely large nerve endings (Fig. $7 E-G$ ). Extraglomerular OMP positive axons penetrating in between the juxtaglomerular cells were always B-50/GAP-43 positive, suggesting that their ectopic growth is caused by the presence of transgenic B-50/GAP-43 (Fig. 7A-D). However, we never observed olfactory fiber growth beyond the juxtaglomerular cells into the external plexiform or mitral cell layers.

Golgi staining of bulbs of three transgenic mice and three nontransgenic litter mates was performed as an alternative, independent method to study individual axon profiles in the olfactory bulb. Axons in the glomerular layer of the olfactory bulb were identified as genuine primary olfactory nerve fibers on the basis of two criteria: (1) only axons that could be followed reliably from the olfactory nerve layer to the interior of a glomerulus were included, and (2) to avoid confusion between olfactory axons and other glomerular fibers, axon profiles derived from the olfactory nerve layer were excluded from our analysis if the glomerulus contained dendritic or axonal structures from other bulb neurons, that is, juxtaglomerular or mitral cells. In Golgi-stained bulbs of transgenic animals we frequently observed axon profiles with varicosities and enlarged nerve endings, thus confirming the observations made by confocal laser scanning microscopy (Fig. 8, right-hand side). In control animals the overall appearance of the fibers was more regular and although some varicosities were seen, these structures were morphologically less striking. Wild type fibers often terminated in a relatively small knob-like structure consistent with previous descriptions of Golgi-stained rat olfactory nerve fibers (Fig. 8, lefthand side; Halasz and Greer, 1993). Primary olfactory wild type fibers never exhibited the terminal enlargements as seen in transgenic animals.

\section{Discussion}

We have generated transgenic mice that express B-50/GAP-43 in adult olfactory neurons, a class of neurons that turns over throughout life and does not normally express B-50/GAP-43. The consequences of directed expression of B-50/GAP-43 on the morphology, growth and turnover of olfactory neurons in their natural cellular and molecular context were studied. The expression of B-50/GAP-43 in adult olfactory neurons in transgenic mice results in the formation of enlarged terminal axons and ectopic primary olfactory projections in the juxtaglomerular cell layer and around blood vessels. Additionally, transgenic expression of B-50/GAP-43 in mature olfactory neurons in the upper portion of the olfactory neuroepithelium results in an intriguing decrease in the normally observed endogenous expression of B-50/GAP-43 in immature neurons in the basal region of the epithelium. This suggests that B-50/GAP-43 expression in mature olfactory neurons could change the dynamics of olfactory neuron turnover. Cell fate studies with BrdU, however, indicate that olfactory neuron turnover and migration are normal.

\section{Olfactory neuron turnover is normal in B-50/GAP-43 transgenic mice}

In the two high expressing transgenic lines (L29 and L33) the temporal and spatial expression of the transgene is consistent with the transcriptional activation of the native OMP gene (Dan- 

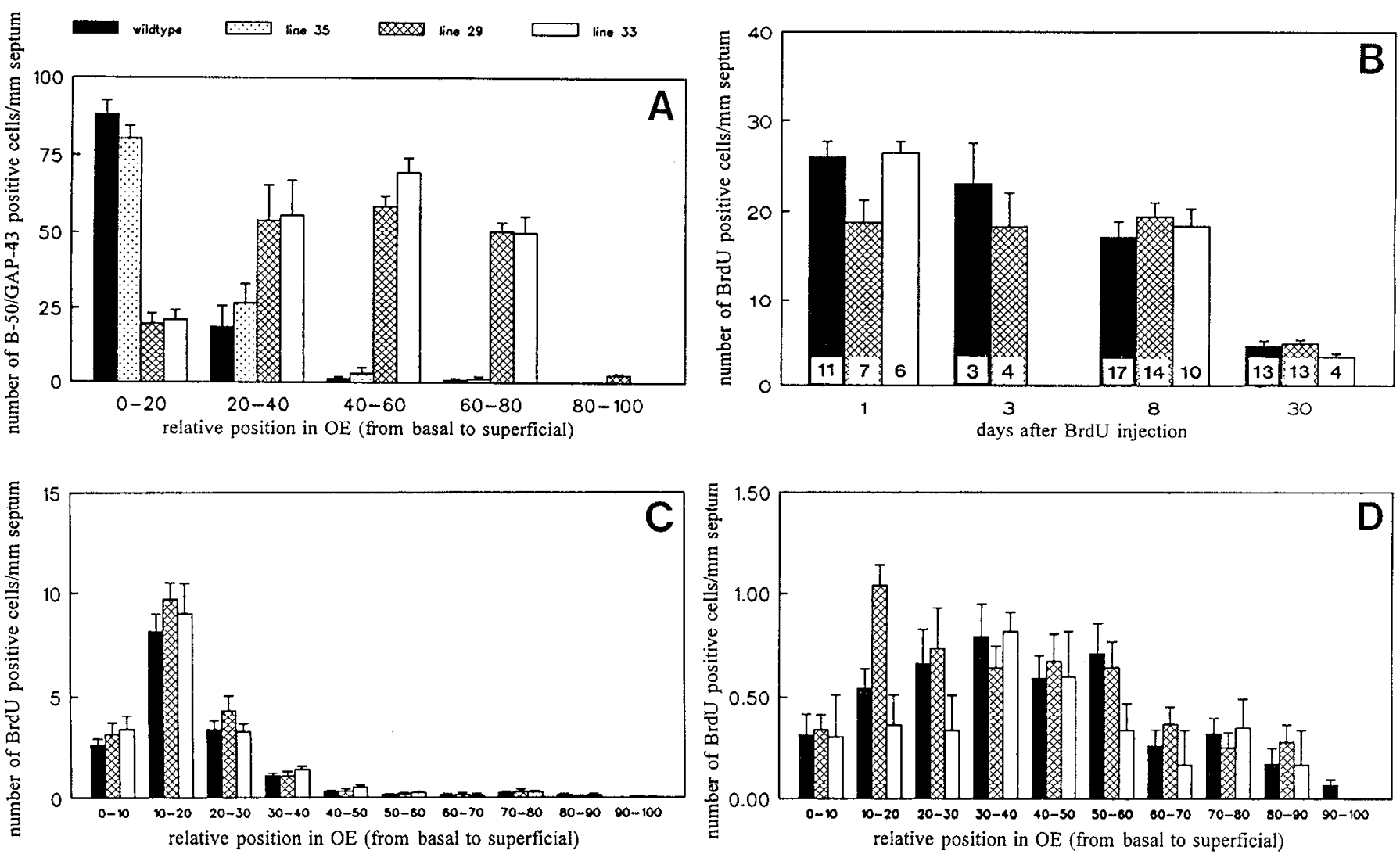

Figure 5. Quantitative assessment of the decrement in B-50/GAP-43 positive cells in the basal epithelium of adult transgenic mice and analysis of basal cell division, migration and survival of cells in the olfactory neuroepithelium. $A$, The distribution of B-50/GAP-43 positive cells was counted in septal epithelium of adult wild type and transgenic mice of L29, L33 (high expressing lines), and L35 (nonexpressing line). For all groups the number of animals was three. Note the decrement in B-50/GAP-43 expressing neurons in the basal region of the epithelium of transgenic mice. $B$, To study the neuronal turnover process in adult mice wild type and transgenic littermates (age 3-4 months) were injected with BrdU. In mice sacrificed at 1, 3,8, and $30 \mathrm{~d}$ following BrdU injection the number of BrdU-positive cells was counted in septal epithelium as detailed in the materials and methods. The total number of cells in the wild type littermates of L29 and L33 did not differ significantly and are presented as pooled data. An independent $t$ test revealed no statistically significant difference between transgenic mice and their wild type littermates at day 1 ( $t=$ 1.72, $p=0.12)$. $C$ and $D$, Relative position of BrdU-labeled olfactory neurons at $8(C)$ and $30 \mathrm{~d}(D)$ following BrdU injection. An ANOVA revealed no statistically significant difference between the position of BrdU-positive cells in transgenic and wild type mice of both L29 and L33 (8 d: L29, $F=1.172, p=0.31 ; \mathrm{L} 33, F=0.344, p=0.96 ; 30$ days: L29, $F=1.297, p=0.24 ; \mathrm{L} 33, F=0.428, p=0.92$ ).

ciger et al., 1989). This corroborates studies using the OMP gene to drive olfactory neuron-specific gene expression in transgenic mice (Danciger et al., 1989; Largent et al., 1993; Walters et al., 1993; Hayward et al., 1994).

In transgenic mice we observed a striking decrease in the normally observed expression of B-50/GAP-43 in neurons in the basal portion of the epithelium. This occurred as early as 5 weeks after birth and was observed throughout adulthood. Normally, in wild type mice a small complement of B-50/GAP-43 positive olfactory neurons is maintained in the basal region of the epithelium. It is thought that these neurons represent a reservoir of cells ready to replace receptor neurons that die (Graziadei and Monti-Graziadei, 1978; Verhaagen et al., 1989; FarbInan, 1990).

The simplest explanation for the dramatically decreased number of B-50/GAP-43 neurons in the basal region of the olfactory epithelium of transgenic mice is that the normally observed turnover of primary olfactory receptor cells (Moulton et al., 1970; Graziadei and Monti-Graziadei, 1978; Farbman, 1990; MackaySim and Kittel, 1991; Schwartz Levey et al., 1991; Carr and Farbman, 1993) has changed in transgenic mice as a consequence of the expression of this growth-associated protein in mature neurons. The current understanding is that both genetic and environmental factors contribute to the mechanisms that regulate olfactory neuron turnover (Farbman, 1990, 1994). The extrinsic factors that affect neurogenesis and lifespan of olfactory neurons are predominantly related to noxious stimuli that enter the nasal cavity. Occlusion of a naris (Farbman et al. 1988) and housing of animals in ultraclean air (Hinds et al., 1984) resulted, respectively, in a reduction of mitotic divisions or in more longlived primary olfactory neurons. These experimental conditions presumably protect existing neurons from harmful extrinsic influences thus prolonging there lifespan.

In the context of these findings, what could be the effect of a growth-associated protein like B-50/GAP-43 on the turnover process and how could these effects explain the decreased number of B-50/GAP-43 positive olfactory neurons in the basal epithelium? First, one could envision that B-50/GAP-43 endows mature olfactory neurons with an enhanced growth and/or repair capacity. This would increase their competence to occupy vacant synaptic space that occurs upon death of an olfactory neuron, thus reducing the demand for the immediate replacement of olfactory connections. The morphological effects induced by B-50/GAP-43 in olfactory axons suggest this is a realistic op- 

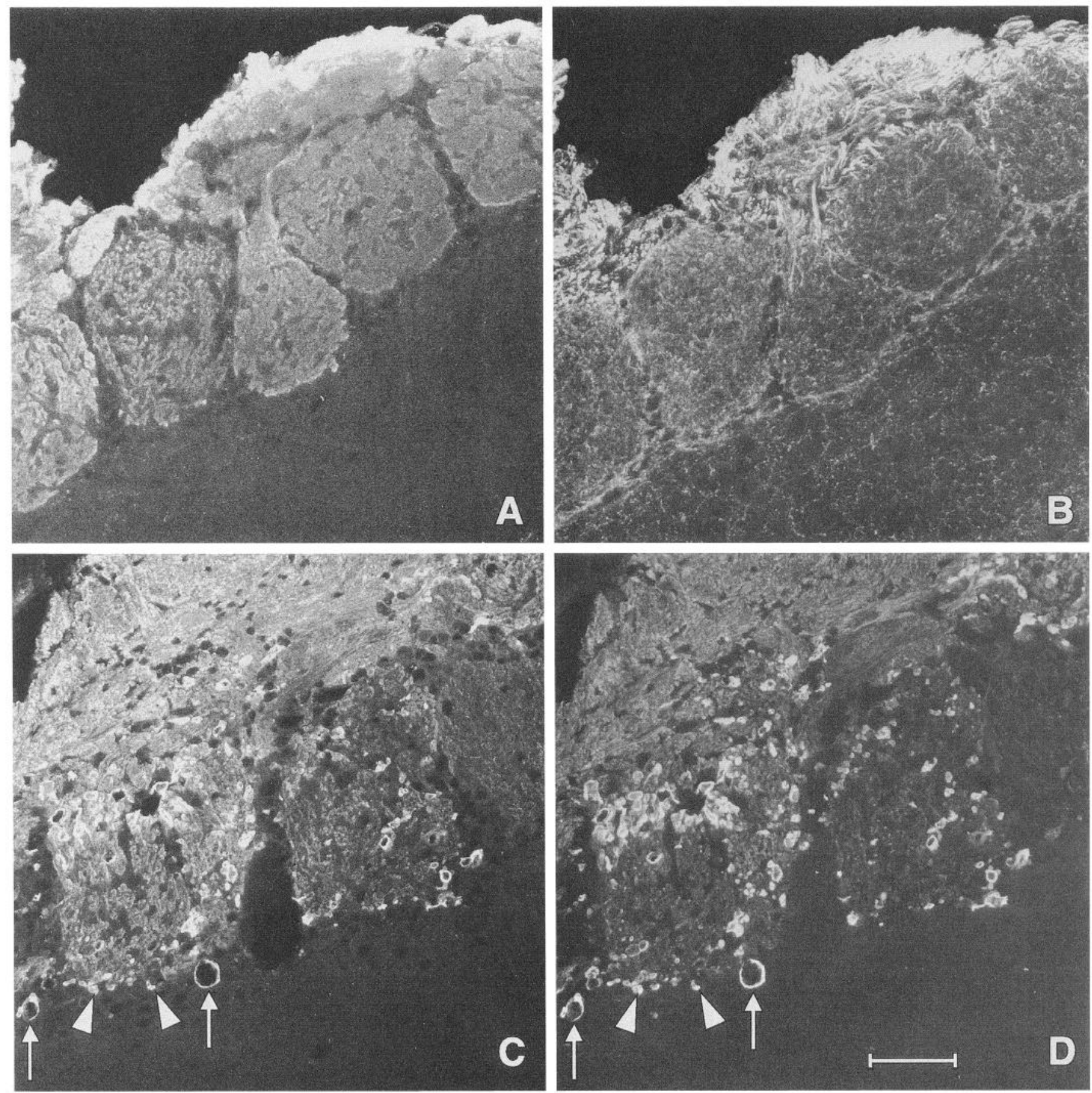

Figure 6. Changes in the pattern of OMP positive primary olfactory axons in the olfactory bulb of transgenic animals. Confocal laser scanning micrographs were taken from a wild type $(A, B)$ and transgenic littermate $(C, D)$ of L29. Olfactory bulb sections are double stained for OMP $(A$, $C)$ and B-50/GAP-43 $(B, D)$. In the bulb of the wild type mouse, visualization of the OMP-signal reveals typical glomeruli with sharp edges, exhibiting a homogeneous pattern of OMP immunoreactivity $(A)$. B-50/GAP-43 staining is largely absent in these glomeruli $(B)$. In the bulb of the transgenic mouse the pattern of OMP positive primary olfactory axons $(C)$ is irregular and corresponds to the B-50/GAP-43 positive "hot spots" $(D)$. Note the OMP- and B-50/GAP-43 double stained "hot spots" at the edges of the glomeruli (arrowheads) and double labeled olfactory nerve fibers around blood vessels (arrows). Scale bar, $50 \mu \mathrm{m}$.

tion. Also, a protective effect of B-50/GAP-43 leading to enhanced repair of neurons damaged by noxious environmental stimulation is conceivable. A second reason for a decreased number of $\mathrm{B}-50 / \mathrm{GAP}-43$ positive cells in the basal region of the transgenic olfactory epithelium could be related to an effect of B-50/GAP-43 on neuronal migration. An accelerated migration of transgenic olfactory neurons into the upper region of the ep- ithelium would lead to a relative loss of B-50/GAP-43 expressing cells from the basal region of the epithelium. Both options could imply that the delicate equilibrium between neurogenesis and olfactory neuron death is affected. Our BrdU-cell fate studies indicate that the decrease in the number of B-50/GAP-43 cells in the basal epithelium is not due to an inherent change in the turnover of olfactory neurons as a result of transgenic ex- 

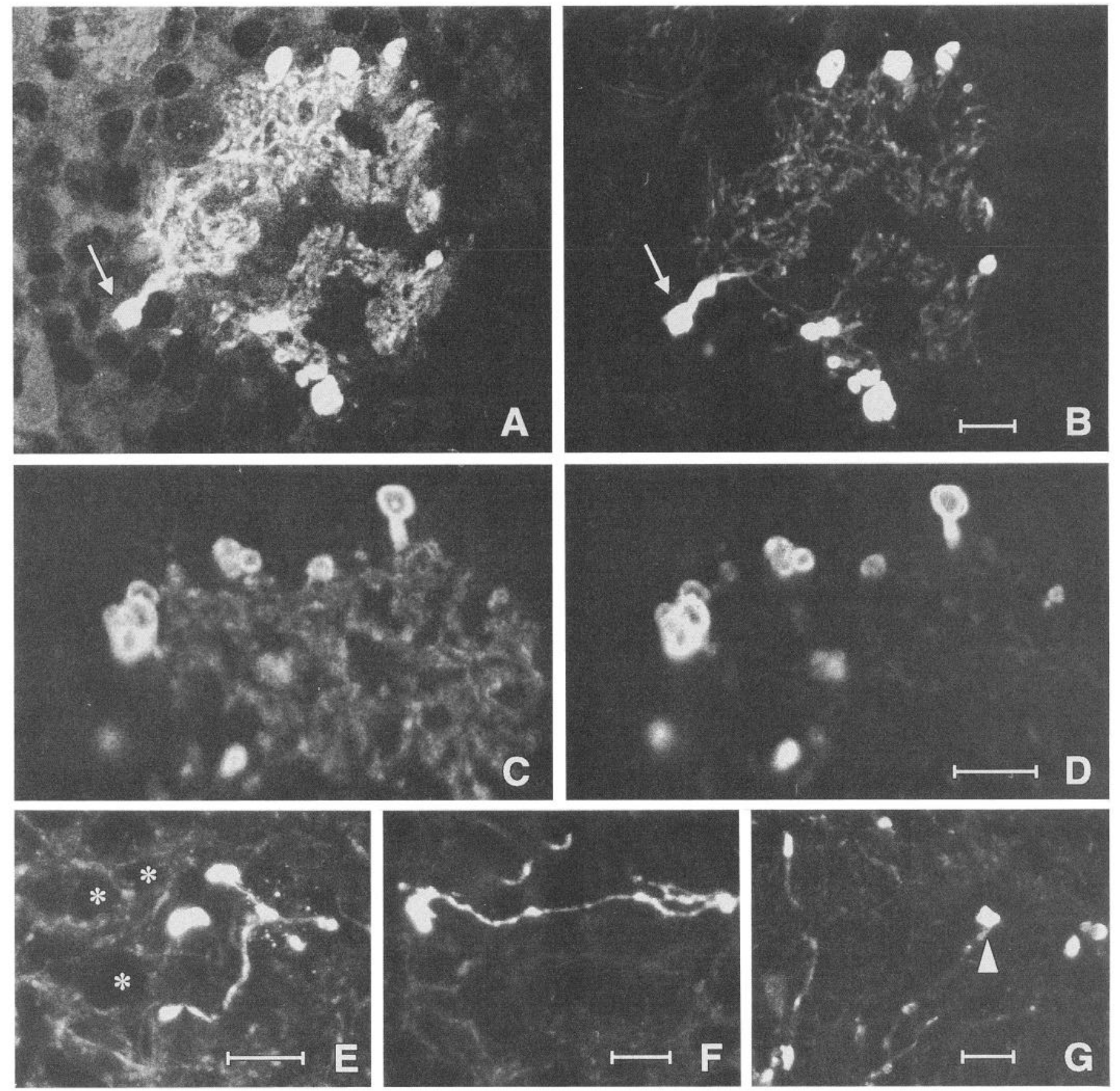

Figure 7. Details of the morphogenic changes observed in primary olfactory axons expressing B-50/GAP-43 in transgenic mice. Confocal laser scanning micrographs were taken from transgenic mice of the high expressing L29 $(C, D)$ and L32, a low expressing line $(A, B, E, F, G)$. Olfactory bulb sections are double stained for $\operatorname{OMP}(A, C)$ and B-50/GAP-43 $(B, D)$. The $E-G$ represent B-50/GAP-43 positive primary olfactory neurons. $A-D$, Typical examples of OMP- and B-50/GAP-43 double stained primary olfactory axons that grow out of the glomerulus, entering the juxtaglomerular layer. Note the thick axon terminal $(A, B$; arrows) extending approximately $15 \mu \mathrm{m}$ beyond the glomerular edge in between juxtaglomerular cells. The nuclei of the juxtaglomerular cells stand out as dark structures in a faint background $(A) . E-G$, Micrographs of primary olfactory axons with dilated nerve endings (indicated by the arrowhead in $G$ ) located on the edge of the glomerulus, often encountering juxtaglomerular cells indicated by asterisks $(E)$. Scale bars, $10 \mu \mathrm{m}$.

pression of $\mathrm{B}-50 / \mathrm{GAP}-43$ in mature neurons. We have as yet no explanation for the observed decrement in B-50/GAP-43 positive immature neurons. However other possible explanations for this phenomenon may be related to changes in interneuronal signaling in the transgenic epithelium or retrograde signaling from the bulb to the epithelium. Future experiments will be designed to shed more light on this issue.

\section{B-50/GAP-43 induces morphogenic effects in adult olfactory neurons}

The present study on the directed expression of B-50/GAP-43 in mature olfactory neurons in transgenic mice demonstrates that this protein exerts morphogenic effects in vivo. The projections of primary olfactory neurons on second order olfactory neurons, the mitral- and juxtaglomerular cells, are organized in a array 

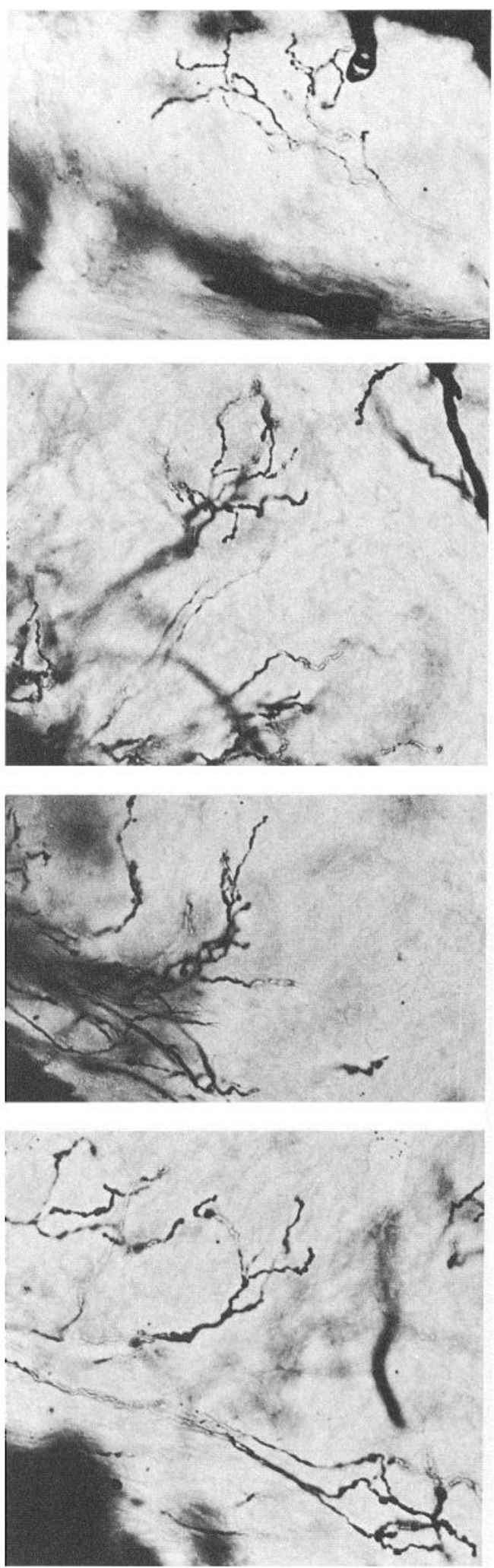
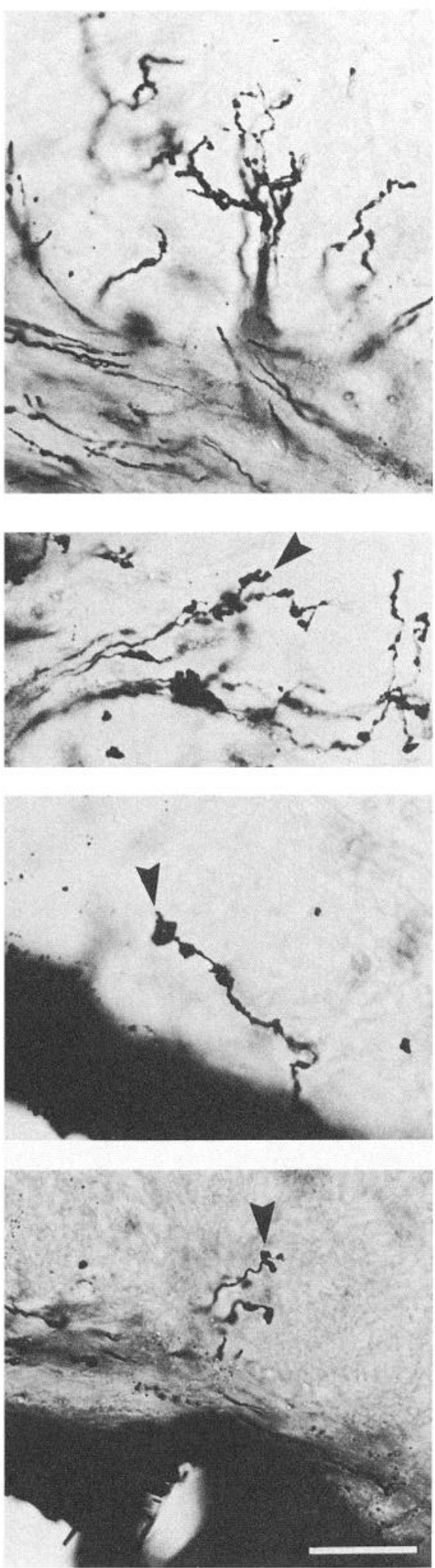

Figure 8. Individual olfactory axons visualized with Golgi-staining in transgenic mice exhibit varicosities. The olfactory bulbs of three wild type and three transgenenic animals from L29 were used for a Golgi-staining to study the appearance of individual primary olfactory axons. The left column of photomicrographs shows examples of primary olfactory fibers from wild type animals and the right column of photomicrographs are taken from transgenic olfactory bulbs. The nerve layer from were the primary olfactory axons project into the glomeruli is always oriented towards the lower edge of the photomicrographs. Note that several fibers in transgenic mice exhibit varicosities (arrows). Scale bar, $50 \mu \mathrm{m}$. of glomeruli positioned at the periphery of the olfactory bulb. Each glomerulus consists of a globular mass of neuropil and its anatomical boundary is well-defined by juxtaglomerular neurons and astroglial cells (Valverde and Lopez-Mascaraque, 1991; Bailey and Shipley, 1993; Gonzalez et al., 1993; Fig. 1A).

In contrast to the situation in wild type mice, we observed the formation of enlarged primary olfactory nerve endings and ectopically localized olfactory fibers in the juxtaglomerular cell layer and in close approximation with blood vessels. Interestingly, these morphological effects are preferentially observed in olfactory axons at the rim of individual glomeruli. One possible explanation is that transgenic B-50/GAP-43 containing olfactory 
fibers have an enhanced growth potential and respond to endogenous growth-promoting factors produced in the juxtaglomerular layers of the olfactory bulb. At the same time, as transgenic B-50/GAP-43 positive fibers encounter repulsive guidance molecules expressed on juxtaglomerular cells that form the cellular boundaries of glomeruli, this results in axons that develop dilated nerve endings or sprout over short distances between juxtaglomerular cells. These morphological phenomena are somewhat reminiscent of the previously documented behavior of distal axon stumps of injured corticospinal neurons (Ramon y Cajal, 1914), cortical neurons (Van Eden and Rinkens, 1994), and cerebellar Purkinje cells (Martinez-Murillo et al., 1993; Dusart and Sotelo, 1994). Injured cerebrospinal neurons do upregulate their B-50/GAP-43 synthesis following injury (Tetzlaff et al., 1991) but their axon stumps fail to regenerate and form terminal varicosities with occasional fibrous spikes apparently in an attempt to sprout over a nonpermissive boundary (Ramon y Cajal, 1914).

This explanation for the B-50/GAP-43 induced morphological phenomena in our transgenic mice is consistent with in vitro results showing differential responses to growth factors and myelin-derived neurite growth inhibitors of B-50/GAP-43-rich growth cones and growth cones that lack B-50/GAP-43. For instance, enhanced expression of B-50/GAP-43 in cultured neuronal cells leads to an increased sprouting response, though only following the application of the appropriate growth stimulus (Yankner et al., 1990; Morton and Buss, 1992). Downregulation of B-50/GAP-43 with antisense oligonucleotides results in a failure to respond to NGF-induced growth cone spreading or IGFstimulated neurite branching (Aigner and Caroni, 1995). These in vitro studies suggest that B-50/GAP-13 amplifies the response of neurons to neurotrophic factors. Recent cell culture and in situ hybridization studies have revealed the presence of neurotrophins (e.g., BDNF) in juxtaglomerular cells and neurotrophic receptors are expressed by primary olfactory neurons (Deckner et al., 1993). This invites the speculation that in analogy with the in vitro results transgenic primary olfactory neurons may have become more sensitive to neurotrophins, resulting in morphogenic changes in their axons. Also, neuronal differentiation of cultured olfactory precursors is stimulated by $\mathrm{TGF}_{2}(\mathrm{Ma}-$ hanthappa and Schwarting, 1993), a peptide growth factor abundantly expressed by endothelial cells in blood vessels (Bobik and Campbell, 1993). It is intriguing in this respect that we frequently observed olfactory fibers associated with blood vessels.

In addition to trophic influences, guidance and repulsive mechanisms are essential in the regulation of neural connections. Neurons devoid of B-50/GAP-43 are particularly sensitive to myelin-derived growth cone inhibitors, while neurites rich in B-50/GAP-43 are "paralyzed" but their growth cones do not retract and collapse as dramatically as B-50/GAP-43-poor growth cones do (Aigner and Caroni, 1995). This suggests that this growth-associated protein may partially protect axons from the repulsive action of growth inhibitors. Analogous to these in vitro observations, B-50/GAP-43 expressing olfactory neurons in transgenic mice may therefore be better able to resist the repulsive molecular forces that constitute glomerular boundaries. The external plexiform layer contains oligodendrocytes, surrounding the glomeruli with their processes and forming myelin sheets around mitral cell dendrites and juxtaglomerular cells bodies (Valverde and Lopez-Mascaraque, 1991). Astrocytes, present around glomeruli (Bailey and Shipley, 1993) express the inhibitory extracellular glycoproteins tenascin and chondrosulfate-proteoglycan (Gonzales et al., 1993). In wild type mice myelin-derived growth inhibitors (Caroni and Schwab, 1988; Schwab et al., 1993) and extracellular glycoproteins may act as stopsignals for immature olfactory axons that enter the glomeruli throughout adulthood. In transgenic olfactory neurons, that overexpress B-50/GAP-43, the inhibitory action of these molecules may be partially overcome especially in the presence of bulbar neurotrophic support.

In conclusion, expression of B-50/GAP-43 in mature olfactory neurons in vivo affects their axonal morphology and leads to abnormal primary olfactory projections. The overall anatomical structure of the typical array of olfactory bulb glomeruli, however, remains largely intact. The data suggest that B-50/ GAP-43 expression in adult neurons increased their growth potential but B-50/GAP-43 is not sufficient to trigger a vigorous sprouting response past predetermined boundaries in the olfactory bulb. In future experiments we will determine the relationship between enhanced B-50/GAP-43 in primary olfactory axons and their capacity to grow by altering the putative juxtaglomerular molecular wall and by local application of neurotrophic factors.

\section{References}

Aigner L, Caroni P (1993) Depletion of 43-kD growth associated protein in primary sensory neurons leads to diminished formation and spreading of growth cones. J Cell Biol 123:417-429.

Aigner L, Caroni P (1995) Absence of persistent spreading, branching, and adhesion in GAP-43-depleted growth cones. J Cell Biol 128:647660.

Baetge EE, Hammang JP (1991) Neurite outgrowth in PC12 cells deficient in GAP-43. Neuron 6:21-30.

Bailey MS, Shipley MT (1993) Astrocyte subtypes in the rat olfactory bulb: morphological heterogeneity and differential laminar distribution. J Comp Neurol 328:501-526.

Benowitz LI, Routtenberg A (1987) A membrane phosphoprotein associated with neural development, axonal regeneration, phospholipid metabolism and synaptic plasticity. Trends Neurosci 10:527-532.

Benowitz LI, Shashoua VE, Yoon MG (1981) Specific changes in rapidly transported proteins during regeneration of the goldfish optic nerve. J Neurosci 1:300-307.

Biffo S, Verhaagen J, Schrama LH, Schotman P, Danho W, Margolis F (1990) B-50/GAP-43 expression correlates with process outgrowth in the embryonic mouse nervous system. Eur J Neurosci 2:487-499.

Bobik A, Campbell JH (1993) Vascular derived growth factors: cell biology, pathophysiology, and pharmacology. Pharmacol Rev 45:142.

Calof AL, Chikaraishi DM (1989) Analysis of neurogenesis in a mammalian ncurocpithclium: proliferation and differcntiation of an olfactory neuron precursor in vitro. Neuron 3:115-127.

Cameron HA, Kaliszewski CK, Greer CA (1991) Organization of mitochondria in olfactory bulb granule cell dendritic spines. Synapse $8: 107-118$.

Caroni P, Schwab ME (1988) Two membrane protein fractions from rat central myelin with inhibitory properties for neurite growth and fibroblast spreading. J Cell Biol 106:1281-1288.

Carr VMM, Farbman AI (1993) The dynamics of cell death in the olfactory epithelium. Exp Neurol 124:308-314.

Danciger E, Mettling C, Vidal M, Morris R, Margolis F (1989) Olfactory marker protein gene: its structure and olfactory neuron-specific expression in transgenic mice. Proc Natl Acad Sci USA 86:85658569.

Dani JW, Armstrong DM, Benowitz LI (1991) Mapping the development of the rat brain by GAP-43 immunocytochemistry. Neuroscience 40:277-287.

Deckner ML, Frisén J, Verge VMK, Hökfelt T, Risling M (1993) Localization of neurotrophin receptors in olfactory epithelium and bulb. Neuroreport 5:301-330

Dusart I, Sotelo C (1994) Lack of Purkinje cell loss in adult rat cerebellum following protracted axotomy: degenerative changes and re- 
generative attempts of the severed axons. J Comp Neurol 347:211232.

Farbman AI (1990) Olfactory neurogenesis: genetic or environmental controls? Trends Neurosci 13:362-365.

Farbman AI (1994) Developmental biology of olfactory sensory neurons. Semin Cell Biol 5:3-10.

Farbman AI, Brunjes PC, Rentfro L, Michas J, Ritz S (1988) The effect of unilateral naris occlusion on cell dynamics in the developing rat olfactory epithelium. J Neurosci 8:3290-3295.

Gonzalez ML, Malemud CJ, Silver J (1993) Role of astroglial extracellular matrix in the formation of rat olfactory bulb glomeruli. Exp Neurol 123:91-105.

Graziadei PPC, Monti Graziadei GA (1978) The olfactory system: a model for the study of neurogenesis and axon regeneration in mammals. In: Ncuronal plasticity (Cotman CW, ed), pp 131-153. New York: Raven.

Halasz N, Greer CA (1993) Terminal arborizations of olfactory nerve fibers in the glomeruli of the olfactory bulb. J Comp Neurol 337: 307:316.

Hayward MD, Bocchiaro C, Morgan JI (1994) Consequences of Bcl-2 overexpression in olfactory receptor neurons of transgenic mice. Soc Neurosci Abstr 20:685.

Hinds JW, Hinds PL, McNelly NA (1984) An autoradiographic study of the mouse olfactory epithelium: evidence for long-lived receptors. Anat Rec 210:375-383.

Hogan BLM, Costantini F, Lacy E (1986) Manipulation of the mouse embryo: a laboratory manual. Cold Spring Harbor, NY: Cold Spring Harbor Laboratory.

Jaenisch R (1988) Transgenic animals. Science 240:1468-1474.

Keller A, Margolis FL (1975) Immunological studies of the rat olfactory marker protein. J Neurochem 24:1101-1106.

Laird PW, Zijderveld A, Linders K, Rudnicki MA, Jaenisch R, Berns A (1991) Simplified mammalian DNA isolation procedure. Nucleic Acids Res 19:4293.

Largent BL, Sosnowski RG, Reed RR (1993) Directed expression of an oncogene to the olfactory neuronal lineage in transgenic mice. $\mathrm{J}$ Neurosci 13:300-312.

Lowry OH, Rosebrough NJ, Farr AL, Randall RJ (1951) Protein measurement with the Folin phenol reagent. J Biol Chem 193:265-275.

Mackay Sim A, Kittel P (1991) Cell dynamics in the adult mouse olfactory epithelium: a quantitative autoradiographic study. J Neurosci 11:979-984.

Mahanthappa NK, Schwarting GA (1993) Peptide growth factor control of olfactory neurogenesis and neuron survival in vitro: roles of EGF and TGF- $\beta$ s. Neuron 10:293-305.

Martinez Murillo R, Caro L, Nieto Sampedro M (1993) Lesion-induced expression of low-affinity nerve growth factor receptor-immunoreactive protein in Purkinje cells of the adult rat. Neuroscience 52:587. 593.

Meiri KF, Bickerstaff LE, Schwob JE (1991) Monoclonal antibodies show that kinase $\mathrm{C}$ phosphorylation of GAP-43 during axogenesis is both spatially and temporally restricted in vivo. J Cell Biol 112:9911005.

Morton AJ, Buss TN (1992) Accelerated differentiation in response to retinoic acid after retrovirally mediated gene transfer of GAP-43 into mouse neuroblastoma cells. Eur J Neurosci 4:910-916.

Moulton DG, Celebi G, Fink RP (1970) Olfaction in mammals - two aspects: proliferation of cells in the olfactory epithelium and sensitivity to odours. In: Taste and smell in vertebrates (Wolstenholme GEW, Knight J, eds), pp 241-252. London: Churchill.

Nielander HL, Schrama LH, Van Rozen AJ, Kasperaitis M, Oestreicher AB, De Graan PNE, Gispen WH, Schotman P (1987) Primary structure of the neuron-specific phosphoprotein B-50 is identical to growth-associated protein GAP-43. Neurosci Res Commmun 1:163172 .

Oestreicher AB, Van Dongen CJ, Zwiers H, Gispen WH (1983) Affinity purified anti-B50 protein antibody: interference with the function of the phosphoprotein B50 in synaptic plasma membranes. J Neurochem 41:331-340.
Palmiter RD, Brinster RL (1986) Germ-line transformation of mice. Annu Rev Genet 20:465-499.

Ramon y Cajal SR (1914) La degeneracion y regeneracion del sistema nervioso, Tomo 2. Madrid: Imprenta de Hijos de Nicolas Moya.

Schwab ME, Kapfhammer JP, Bandtlow CE (1993) Inhibitors of neurite growth. Annu Rev Neurosci 16:565-595.

Schwartz Levey M, Chikaraishi DM, Kauer JS (1991) Characterization of potential precursor populations in the mouse olfactory epithelium using immunocytochemistry and autoradiography. J Neurosci 11: $3556-3564$.

Schwob JE, Mieleszko Szumowski KE, Stasky AA (1992) Olfactory sensory neurons are trophically dependent on the olfactory bulb for their prolonged survival. J Neurosci 12:3896-3919.

Shea TB, Perrone Bizzozero NI, Beermann ML, Benowitz LI (1991) Phospholipid-mediated delivery of anti-GAP-43 antibodies into neuroblastoma cells prevents neuritogenesis. J Neurosci 11:1685-1690.

Skene JHP (1989) Axonal growth-associated proteins. Annu Rev Neurosci 12:127-156.

Skene JHP, Willard M (1981a) Axonally transported proteins associated with axon growth in rabbit central and peripheral nervous system. J Cell Biol 89:96-103.

Skene JHP, Willard M (1981b) Changes in axonally transported proteins during axonal regeneration in toad retinal ganglion cells. J Neurosci $1: 419-426$.

Strittmatter SM, Fankhauser C, Huang PL, Mashimo H, Fishman MC (1995) Neuronal pathfinding is abnormal in mice lacking the neuronal growth cone protein GAP-43. Cell 80:445-452.

Tetzlaff W, Alexander SW, Miller FD, Bisby MA (1991) Response of facial and rubrospinal neurons to axotomy: changes in mRNA expression for cytoskeletal proteins and GAP-43. J Neurosci 11:25282544.

Towbin H, Steahelin T, Gordon J (1984) Electrophoretic transfer of proteins from polyacrylamide gels to nitrocellulose sheets: procedure and application. Proc Natl Acad Sci USA 76:4354-4356.

Valverde F, Lopez-Mascaraque L (1991) Neuroglial arrangements in the olfactory glomeruli of the hedgehog. J Comp Neurol 307:658674.

Van Eden CG, Rinkens A (1994) Lesion induced expression of lowaffinity NGF-binding protein (p75) immunoreactivity after neonatal and adult aspiration lesions of the rat dorsomedial prefrontal cortex. Dev Brain Res 82:167-174.

Verhaagen J, Oestreicher AB, Edwards PM, Veldman H, Jenekens FGI, Gispen WH (1988) Light and electron microscopical study of phosphoprotein $\mathrm{B}-50$ following denervation and reinnervation of the rat soleus muscle. J Neurosci 8:1759-1766.

Verhaagen J, Oestreicher AB, Gispen WH, Margolis FL (1989) The expression of the growth-associated protein B-50/GAP-43 in the olfactory system of neonatal and adult rats. J Neurosci 9:683-691.

Verhaagen J, Hermens WTJMC, Oestreicher AB, Gispen WH, Rabkin SD, Pfaff DW, Kaplitt MG (1994) Expression of the growth-associated protein B-50/GAP-43 via a defective herpes-simplex virus vector results in profound morphological changes in non-neuronal cells. Mol Brain Res 26:26-36.

Walters E, Grillo M, Kudrycki K, Bocchiaro C, Philips A, Margolis FL (1993) Transgenic analysis of the OMP promoter. Soc Ncurosci Abstr 19:1121.

Widmer F, Caroni P (1993) Phosphorylation site mutagenesis of the growth-associated protein GAP-43 modulates its efrects on cell spreading and morphology. J Cell Biol 120:503-512.

Yankner GA, Benowitz LI, Villa Komaroff L, Neve RL (1990) Transfection of PC12 cells with the human GAP-43 gene: effects on neurite outgrowth and regeneration. Mol Brain Res 7:39-44.

Zuber MX, Goodman DW, Karns LR, Fishman MC (1989) The neuronal growth-associated protein GAP-43 induces filopodia in nonneuronal cells. Science 244:1193-1195.

Zwiers H, Veldhuis HD, Schotman P, Gispen WH (1976) Cyclic nucleotides, and brain protein phosphorylation in vitro. Neurochem Res $1: 669-677$.

Zwiers H, Wiegant VM, Schotman P, Gispen WH (1978) ACTH-induced inhibition of endogenous rat brain protein phosphorylation in vitro: structure activity. Neurochem Res 3:455-463. 